\title{
ANALISIS EVALUASI PERKEMBANGAN SOSIAL ANAK DI TAMAN KANAK-KANAK ASSALAM 2 SUKARAME BANDAR LAMPUNG
}

\author{
Reiska Primanisa \\ Universitas Islam Negeri Sunan Kalijaga \\ reiskapn@gmail.com
}

\begin{abstract}
Based on the results of observations of researchers, it was found that in Assalam 2 Sukarame Kindergarten in Bandar Lampung using social development evaluation in accordance with the early childhood assessment system, besides that many obtained daily notes of children in the classroom. This prompted researchers to conduct an evaluation of social development evaluations in Assalam 2 Sukarame Kindergarten in Bandar Lampung.

Assessment in early childhood education is the process of collecting and processing information (data) in determining the level of achievement of children 0-6 years old development. The purpose of this study was to determine how the evaluation of children's social development evaluation and whether the evaluation of social development of group A children conducted in Assalam 2 Kindergarten in Sukarame Bandar Lampung was in accordance with the PAUD assessment system.

This study uses descriptive qualitative research, the object of this study is an analysis of social development evaluation in Assalam Kindergarten 2 Sukarame Bandar Lampung. Data collection tools used are observation, interviews, and documentation, as well as analyzing the results of research researchers make conclusions by inductive.

Based on the results of the study it can be seen that the evaluation of children's social development in Assalam 2 Sukarame Kindergarten Bandar Lampung has been successfully carried out. This can be seen when the teacher classifies the activities carried out, the results of the daily assessment, the work described, and other notes, then the researcher documents, analyzes and concludes. Analysis of children's social development evaluation requires appropriate time and assessment tools to conduct assessments and evaluations. And there is a close relationship between assessment, evaluation and curriculum that is right for children.
\end{abstract}

\section{Keywords: Evaluation Analysis, Social Development}




\begin{abstract}
ABSTRAK
Berdasarkan hasil oservasi peneliti, didapatkan data bahwa di Taman KanakKanak Assalam 2 Sukarame Bandar Lampung menggunakan evaluasi perkembangan sosial sesuai dengan sistem penilaian anak usia dini, selain itu banyak didapat catatansehari-hari anak di kelas.Hal ini mendorong peneliti untuk melakukan analisis evaluasi perkembangan sosial di Taman Kanak-Kanak Assalam 2 Sukarame Bandar Lampung.

Penilaian pada pendidikan anak usia dini merupakan proses pengumpulan dan pengolahan informasi(data) dalam menentukan tingkat pencapaian perkembangan anak 0-6 tahun.Adapun tujuan penelitian ini untuk mengetahui bagaimana analisis evaluasi perkembangan sosial anak dan apakah evaluasi perkembangan sosial anak kelompok A yang dilakukan di Taman Kanak-Kanak Assalam 2 Sukarame Bandar Lampung sudah sesuai dengan sistem penilaian PAUD.

Penelitian ini mengunakan penelitian deskriptif kualitatif,objek penelitian ini adalah analisis evaluasi perkembangan sosial di Taman Kanak-Kanak Assalam 2 Sukarame Bandar Lampung. Alat pengumpul data yang digunakan adalah observasi, wawancara, dan dokumentasi, serta menganalisis hasil penelitian peneliti melakukan penarikan kesimpulan dengan cara induktif.

Berdasarkan hasil penelitian dapat diketahui bahwa evaluasi perkembangan sosial anak di Taman Kanak-Kanak Assalam 2 Sukarame Bandar Lampung sudah berhasil dilaksanakan. Hal ini terlihat pada saat guru mengklasifikasi kegiatan yang dilakukan, hasil penilaian harian, hasil karya yang dideskripsikan, dan catatan lainnya, kemudian peneliti mendokumentasikan, menganalisis dan menyimpulkan. Analisis evaluasi perkembangan sosial anak memerlukan waktu dan alat penilaian yang tepat untuk melakukan penilaian dan evaluasi.Dan adanya hubungan yang erat antara penilaian, evaluasi, dan kurikulum yang tepat bagi anak.
\end{abstract}

\title{
Kata Kunci: Analisis Evaluasi, Perkembangan Sosial
}

\section{A. PENDAHULUAN}

Evaluasi dalam pembelajaran anak usia dini berdasarkan Peraturan Menteri Pendidikan dan Kebudayaan Repubik Indonesia Nomor 146 Tahun 2014 Tentang Kurikulum 2013 Pendidikan Anak Usia Dini BAB VI Standar Penilaian Pasal 18 ayat 1 yang berbunyi standar penilaian merupakan kriteria tentang penilaian pross dan hasil pembelajaran anak dalam rangka pemenuhan standar tingkat pencapaian perkembangan sesuai tingkat usianya, ayat 2 yang berbunyi penilaian proses dan hasil pembelajaran anak mencakup: a. prinsip penilaian, b. tehnik dan instrument 
penelitian, c. mekanisme penilaian, d. pelaksanaan penilaian, dan e. pelaporan hasil penilaian. ${ }^{1}$

Menurut Campbell dan Ruptic pelaporan perkembangan anak disusun melalui proses analisis sintesis, interpretasi, dan komunikasi. ${ }^{2}$ Dalam proses analisis dan sintesis, guru mengumpulkan data hasil pengukuran perkembangan yang telah dilakukannya untuk semua aspek perkembangan dan mengamati karakteristik perkembangan yang terlihat pada anak.

Menurut Gardner yang dikutip oleh Mulyasa penilaian adalah penilaian yang dilakukan dengan menetapkan sejauh mana kemampuan telah dimiliki seseorang dari suatu kegiatan pembelajaran atau kegiatan dalam rentang waktu tertentu. ${ }^{3}$ Penilaian pada anak usia dini paling tidak berfungsi :

1. Memberikan umpan balik dalam proses dan hasil pembelajaran,

2. Sebagai bahan pertimbangan untuk bimbingan dan penempatan anak,

3. Sebagai hasil diagnostik terhadap kekurangan atau permasalahan yang dihadapi anak,

4. Sebagai refrensi bagi guru pada pendidikan selanjutnya. ${ }^{4}$

Tujuan evaluasi ini adalah untuk mengumpulkan data dengan berbagai cara sebagai bahan pertimbangan dalam merencanakan stimulasi perkembangan selanjutnya.Sehingga evaluasi ini ditekankan pada proses dari pada hasil. Interpretasi yang dilakukan guru didasarkan pada indikator perkembangan yang telah ditetapkan untuk semua aspek perkembangan anak pada rentang usia tertentu baik sesuai standar

${ }^{1}$ Peraturan Mentri Pendidikan Nomor 146 Tahun 2014 Tentang Kurikulum 2013 Pendidikan Anak Usia Dini

${ }^{2}$ Luluk Asmawati, Perencanaan Pembelajaran PAUD, (Bandung, PT Remaja Rosdakarya,2014), h. 115

${ }^{3}$ Mulyasa,Manajemen PAUD, ( Bandung, PT Remaja Rosdakarya,2012), h. 205

${ }^{4}$ Manispal, Op.Cit, h. 283 
kurikulum yang ditetapkan oleh guru sendiri maupun standar perkembangan anak yang sesuai tingkat usianya. ${ }^{5}$

Setiap hari guru melakukan penilaian atau evaluasi, dalam hal ini ada beberapa hal yang dapat dilakukan oleh guru. Antara lain pengamatan langsung, mencatat kegiatan yang dilakukan dan tahap main anak, mencatat ungkapan, pertanyaan (tanya jawab), pertanyaan anak, membaca hasil karya anak,mendokumentasikan semua bahasa natural anak kedalam portofolio masing-masing anak. ${ }^{6}$

Adapun teknik-teknik evaluasi perkembangan anak usia dini guru harus mampu membuat laporan yang otentik berdasarkan fakta yang terjadi pada anak, guru perlu mencatat dan mengamatinya, guru perlu memeriksa kumpulan catatan dan rekaman tersebut, guru perlu menganalisis tentang berbagai aspek perkembangan yang telah dihimpun. ${ }^{7}$ Kemudian langkah-langkah penilaian pendidikan anak usia dini dapat dilakukan dengan merumuskan kegiatan, menyiapkan alat penilaian, memetapkan kriteria penilaian,dan pelaporan hasil penilaian. ${ }^{8}$

Didalam pembelajaran yang bermutu dan dianggap dapat mengantarkan anak usia dini berkembang sesuai harapan adalah layanan yang terus-menerus dievaluasi(dinilai) atau ditindak lanjuti secara tepat. Seperti Rencana Kegiatan Harian (RKH), jadwal kegiatan, buku laporan perkembangan anak, Catatan anekdot, fotofoto/vidio kegiatan anak, portofolio tiap anak, buku komunikasi antara orangtua dan guru.

Pada saat peneliti bertemu dengan guru dalam berbagai kegiatan dan hasil pengamatan dalam kegiatan pembelajaran mengaku telah melaksanakan kegiatan bermain sambil belajar dan belajar melalui bermain. ${ }^{9}$ kesempatan yang diberikan untuk bermain tidak hanya saat jam istirahat saja tapi sepenuhnya pada kegiatan awal, inti, dan penutup. Diketahui jumlah peserta didik kelas A di Taman Kanak-Kanak

\footnotetext{
${ }^{5}$ Luluk Asmawati, Op.Cit, h 116

${ }^{6}$ Mukhtar Latif, Loc. Cit.

${ }^{7}$ Ibid, h. 118

${ }^{8}$ Mulyasa, Op.Cit, h. 206

${ }^{9}$ Berta Oktaria, wawancara dengan penuis, Taman Kanak-Kanak Assalam 2 Sukarame,
} Bandar Lampung, 12 Januari 2015 
Assalam Sukarame 2 Bandar Lampung murid laki-laki 14 orang, murid perempuan 6 orang sehingga total murid 20 orang.

Tabel 1

Hasil Prasurvey Perkembangan Sosial Anak Di Taman Kanak-Kanak Assalam 2 Sukarame Bandar Lampung

\begin{tabular}{|c|c|c|c|c|c|c|c|c|c|}
\hline \multirow[t]{2}{*}{ No } & \multirow[t]{2}{*}{ Nama } & \multicolumn{7}{|c|}{ Perkembangan Sosial Anak } & \multirow[t]{2}{*}{ Ket } \\
\hline & & 1 & 2 & 3 & 4 & 5 & 6 & 7 & \\
\hline 1 & Ahmad Siddiq. N & MB & MB & $\mathrm{BSH}$ & $\mathrm{BSH}$ & MB & $\mathrm{BSH}$ & $\mathrm{BSH}$ & \\
\hline 2 & Arsyad M. Fahmi & $\mathrm{BB}$ & MB & $\mathrm{BSH}$ & $\mathrm{MB}$ & BB & MB & $\mathrm{BSH}$ & \\
\hline 3 & Athira Putri & BB & BB & BB & BB & BB & BB & $\mathrm{BB}$ & \\
\hline 4 & Carissa Ardhani & MB & MB & MB & MB & MB & MB & BB & \\
\hline 5 & $\begin{array}{l}\text { Fatih Arkana } \\
\text { Mandiri }\end{array}$ & $\mathrm{BSH}$ & MB & MB & $\mathrm{BSH}$ & MB & MB & $\mathrm{BSH}$ & \\
\hline 6 & $\begin{array}{l}\text { Galang Fitra } \\
\text { Priyanto }\end{array}$ & MB & MB & MB & MB & $\mathrm{BSH}$ & $\mathrm{BSH}$ & $\mathrm{BSH}$ & \\
\hline 7 & Hanif Ihsan Kamil & MB & BB & MB & MB & MB & $\mathrm{BSH}$ & MB & \\
\hline 8 & Joko Saputra & MB & $\mathrm{BB}$ & MB & MB & MB & $\mathrm{BSH}$ & $\mathrm{MB}$ & \\
\hline 9 & Kalila salsabila.F & $\mathrm{BSH}$ & MB & MB & $\mathrm{BSH}$ & $\mathrm{BSH}$ & $\mathrm{BSH}$ & MB & \\
\hline 0 & $\begin{array}{l}\text { M. ali Akbar A1 } \\
\text { Abrar }\end{array}$ & $\mathrm{BB}$ & $\mathrm{MB}$ & $\mathrm{BSH}$ & MB & MB & $\mathrm{BSH}$ & MB & \\
\hline 11 & M. Kadafi Dasvila P & MB & MB & MB & $\mathrm{BSH}$ & MB & MB & MB & \\
\hline 12 & M. Nabih Hakim J & MB & BB & MB & MB & BB & MB & MB & \\
\hline 13 & M. Rafa Ha'il Arlie & $\mathrm{BM}$ & BB & BB & $\mathrm{BB}$ & $\mathrm{MB}$ & $\mathrm{BB}$ & $\mathrm{MB}$ & \\
\hline 14 & Nurul Hasanah & $\mathrm{MB}$ & BB & $\mathrm{BB}$ & $\mathrm{BB}$ & MB & $\mathrm{BB}$ & BB & \\
\hline 15 & Pamela Naza Putri & $\mathrm{BSH}$ & $\mathrm{BSH}$ & MB & MB & $\mathrm{BSH}$ & $\mathrm{BSH}$ & $\mathrm{BSH}$ & \\
\hline 16 & Rafa Reynaru & MB & $\mathrm{BSH}$ & MB & $\mathrm{BSH}$ & $\mathrm{BSH}$ & MB & $\mathrm{BSH}$ & \\
\hline 17 & Rafif M. Ridho & MB & BB & MB & $\mathrm{BSH}$ & $\mathrm{BSH}$ & BB & $\mathrm{MB}$ & \\
\hline 18 & Shirath Arkan Anta & $\mathrm{BM}$ & MB & $\mathrm{BB}$ & $\mathrm{MB}$ & $\mathrm{BSH}$ & MB & $\mathrm{MB}$ & \\
\hline 19 & Syafa A1 Zena & MB & $\mathrm{BSH}$ & MB & $\mathrm{MB}$ & $\mathrm{BSH}$ & $\mathrm{BSH}$ & $\mathrm{MB}$ & \\
\hline 20 & Vanesa Putri Y andini & $\mathrm{BM}$ & BB & BB & MB & MB & MB & MB & \\
\hline
\end{tabular}

Sumber: Hasil Dokumentasi Catatan Kegiatan Harian Anak dan Wawancara Guru, Tanggal 12 Januari $2015^{10}$

Keterangan:

1. Mau meminjamkan miliknya dengan senang hati

2. Mau berbagi dengan teman

${ }^{10}$ dokumentasi hasil pra survey perkembangan sosial kelompok A, Taman Kanak-Kanak Assalam 2 Sukarame Bandar Lampung, 12 Januari 2015. 
3. Bersedia bermain dengan teman

4. Dapat atau suka menolong

5. Dapat bekerjasama dalam menyelesaikan tugas

6. Berani tampil di depan umum

7. Menunjukkan kebangaan terhadap hasil kerjanya

BB : Belum Berkembang

MB : Mulai Berkembang

BSH : Berkembang Sesuai Harapan

Dalam kegiatan pembelajaran di Taman Kanak-Kanak Assalam 2 Sukarame Bandar Lampung yang dilihat berdasarkan prasurvey dalam berbagai situasi kegiatan anak didalam atau diluar kelas belum semua berkembang sesuai harapan. Pada saat peneliti melakukan wawancara dengan ibu Berta guru kelas A tanggal 12 Januari 2015 di Taman Kanak-Kanak Assalam 2 Sukarame Bandar Lampung mengatakan bahwa selama pebelajaran berlangsung guru telah melakukan evaluasi pada setiap kegiatan dan meneruskan evaluasi selanjutnya dengan melihat anak-anak yang belum berkembang sesuai harapan pada indikator-indikator diperkembangan sosial kemudian diberikan perbaikan dan pengayaan. ${ }^{11}$

Seperti saat bermain didalam atau diluar kelas beberapa anak masih belum mau bermain bersama dan cenderung bermain sendiri-sendiri, beberapa anak belum dapat bekerjasama dalam menyelesaikan tugas, hampir seluruh anak berani tampil di depan umum, dan saat duduk di bangku beberapa anak terlihat kurang fokus terlihat dari sikap duduknya yang goyang-goyang.

Dari latar belakang diatas penulis ingin mengetahui bagaimana evaluasi perkembangan sosial anak di Taman Kanak-Kanak Assalam 2 Sukarame Bandar Lampung dan apakah evaluasi perkembangan sosial di Taman Kanak-Kanak Assalam 2 Sukarame Bandar Lampung sudah sesuai dengan sistem penilaian PAUD.

\footnotetext{
${ }^{11}$ Berta Oktaria, wawancara dengan peneliti, TK Assalam 2 Sukarame Bandar Lampung, Lampung, 12 Januari 2015.
} 


\section{B. METODE PENELITIAN}

Karena fokus penelitian ini bertujuan untuk menganalisis tentang evaluasi perkembangan sosial anak, maka penelitian ini merupakan jenis penelitian lapangan yang penelitiannya berorientasi pada pengumpulan data empiris dilapangan. ${ }^{12}$ Kemudian ditinjau dari pendekatannya penulis menggunakan Penelitian bersifat deskriptif kualitatif,objek penelitian ini adalah analisis evaluasi perkembangan sosial di Taman Kanak-Kanak Assalam 2 Sukarame Bandar Lampung. Alat pengumpul data yang digunakan adalah observasi, wawancara, dan dokumentasi, serta menganalisis hasil penelitian peneliti melakukan penarikan kesimpulan dengan cara induktif.

\section{HASIL DAN PEMBAHASAN}

peneliti menggunakan instrumen yang berisi daftar penilaian yang dilaksanakan setiap kegiatan berlagsung, kemudian catatan harian anak(anekdot), buku analisis evaluasi, buku perbaikan dan pengayaan, portofolio, buku kegiatan, hingga buku laporan perkembangan anak. ${ }^{13}$ Instrument ini dilakukan untuk lebih memudahkan peneliti menganalisis evaluasi perkembangan sosial anakdi Taman Kanak-Kanak Assalam 2 Sukarame Bandar Lampung. Berikut penulis mendeskriptifkan hasil observasi dan wawancara di Taman Kanak-Kanak Assalam 2 Sukarame Bandar Lampung.

\section{Evaluasi Perkembangan Sosial Anak Kelas A di Taman Kanak-Kanak Assalam 2 Sukarame Bandar Lampung}

Setelah guru membuat rencana kegiatan harian 1, minggu keenam tema sub tema pekerjaan/macam-macam(dokter). Indikator sosialnya yaitu sabar menunggu giliran tujuannya anak anak mampu mentaati aturan dalam suatu permainan dengan kegiatan pembelajaran anak-anak bermain sebagai dokter dan pasien. Guru mengisi lembar

\footnotetext{
${ }^{12}$ Mansur Muchlish, Bagaimana Menulis Skripsi,(Jakarta, Bumi Aksara, 2009), h. 9.

${ }^{13}$ Peneliti, hasil observasi, taman Kanak-Kanak Assalam 2 Sukarame Bandar Lampung, 19
} Juni 2015 
penilaian, kemudian mengisi buku analisis evaluasi, memindahkan dalam buku perbaikan dan pengayaan, dan mengisi buku bimbingan konseling. dan membuat 5 catatan anekdot diantaranya Amel, Kakal, Atira, M.Rafa, sirat tafsiran positif. ${ }^{14}$

Recana kegiatan harian 2, minggu ketujuh tema sub tema pekerjaan/macammacam(tukang bangunan). Indikator sosialnya mengikuti aturan permainan.Tujuannya anak mampu mengenal benda disekitarnya.Guru mengisi lembar penilaian, kemudian mengisi buku analisis evaluasi, memindahkan dalam buku perbaikan dan pengayaan, dan mengisi buku bimbingan konseling. Guru mencatat 5 catatan anekdot diantaranya Ridho, Putra, Hanif, Fahmi tafsiran positif. Nurul tafsiran negatif. ${ }^{15}$

Rencana Kegiatan Harian 3, minggu kesembilan tema sub tema air,udara,api/kegunaan manfaat air(mancing ikan). Indikator sosialnya berhenti bermain pada waktunya.Tujuannya melatih kerjasama anak.Guru mengisi lembar penilaian, kemudian mengisi buku analisis evaluasi, memindahkan dalam buku perbaikan dan pengayaan, dan mengisi buku bimbingan konseling. Guru menulis 5 catatan anekdot diantranya abrar dan galang tafsiran positif. Atira, Nurul, M. Rafa tafsiran negatif. ${ }^{16}$

Rencana Kegiatan Harian 4, minggu kesepuluh tema sub tema air,udara,api/kegunaan manfaat air(memasukan air kedalam botol). Indikator sosialnya mengikuti lomba dalam permainan.Tujuannya melatih kerjasama anak. Kemudian Guru mengisi lembar penilaian, kemudian mengisi buku analisis evaluasi, memindahkan dalam buku perbaikan dan pengayaan, dan mengisi buku bimbingan

\footnotetext{
${ }^{14}$ Peneliti, Hasil observasi, Taman Kanak-Kanak Assalam 2 Sukarame Bandar Lampung, 10 Februari 2015. Februari 2015

${ }^{15}$ Peneliti, Hasil observasi, Taman Kanak-Kanak Assalam 2 Sukarame Bandar Lampung, 17 Maret 2015

${ }^{16}$ Peneliti, Hasil observasi, Taman Kanak-Kanak Assalam 2 Sukarame Bandar Lampung,3
} 
konseling. Guru menulis 4 catatan anekdot diantaranya Nurul, Sirat, Galang dan Siddiq tafsiran positif. ${ }^{17}$

Rencana Kegiatan Harian 5, minggu kesebelas tema sub tema air,udara,api/kegunaan manfaat udara(meniup balon). Indikator sosialnya saling membantu sesama teman.Tujuannya melatih motorik anak.Guru mengisi lembar penilaian, kemudian mengisi buku analisis evaluasi, memindahkan dalam buku perbaikan dan pengayaan, dan mengisi buku bimbingan konseling. Guru membuat 5 catatan anekdot diantaranya Putra, Ridho, Hanif, Nurul tafsiran positif, dan Sirat tafsiran negatif. ${ }^{18}$

Rencana Kegiatan Harian 6, minggu keduabelas tema sub tema air,udara,api/kegunaann manfaat api(lilin). Indikator sosialnya mengajarkan anak untuk berbicara dengan teman tidak berteriak. Tujuannya melatih anak menghargai orang lain. Guru mengisi lembar penilaian, kemudian mengisi buku analisis evaluasi, memindahkan dalam buku perbaikan dan pengayaan, dan mengisi buku bimbingan konseling. Guru membuat 3 catatan anekdot diantaranya Abrar, M. Rafa tafsiran psitif, dan Sirat tafsiran negatif. ${ }^{19}$

Rencana kegiatan harian 7, minggu ketigabelas tema sub tema alat komunikasi/kegunaan alat komunikasi( Koran). Indikator sosialnya dapat menerima pendapat orang lain. Tujuannya anak mampu menghargai pendapat teman.Guru mengisi lembar penilaian, kemudian mengisi buku analisis evaluasi, memindahkan dalam buku perbaikan dan pengayaan, dan mengisi buku bimbingan konseling. Guru membuat 5 catatan anekdot diantaranya Kakal, Galang, Siddiq, Amel tafsiran positif, dan Hakim negtif. ${ }^{20}$

\footnotetext{
${ }^{17}$ Peneliti, Hasil observasi, Taman Kanak-Kanak Assalam 2 Sukarame Bandar Lampung, 13 Maret 2015

${ }^{18}$ Peneliti, Hasil observasi, Taman Kanak-Kanak Assalam 2 Sukarame Bandar Lampung, 18 Maret 2015 Maret 2015

${ }^{19}$ Peneliti, Hasil observasi, Taman Kanak-Kanak Assalam 2 Sukarame Bandar Lampung, 25

${ }^{20}$ Peneliti, Hasil observasi, Taman Kanak-Kanak Assalam 2 Sukarame Bandar Lampung, 2 April 2015
} 
Rencana Kegiatan Harian 8, minggu keempatbelas tema sub tema alat komunikasi/macam-macam alat komukasi(telepon). Indikator sosialnya memberi dan membalas salam. Tujuannya anak mampu berkomunikasi dengan orang lain. Guru mengisi lembar penilaian, kemudian mengisi buku analisis evaluasi, memindahkan dalam buku perbaikan dan pengayaan, dan mengisi buku bimbingan konseling. Guru menulis 4 catatan anekdot diantaranya Kakal, Atira, Abrar, Reynaru tafsiran positif. ${ }^{21}$

Rencana kegiatan harian 9, minggu ke lima belas tema sub tema tanah airku(upacara). Indikator sosialnya menaati aturan sekolah.Tujuannya melatih disiplin anak.Guru mengisi lembar penilaian, kemudian mengisi buku analisis evaluasi, memindahkan dalam buku perbaikan dan pengayaan, dan mengisi buku bimbingan konseling. Guru membuat 4 catatan anekdot diantaranya Putra, Hakim, Reynaru dan galang tafsiran positif. ${ }^{22}$

\section{Analisis Evaluasi Perkembangan Sosial Anak Kelas A Di Taman Kanak- Kanak Assalam 2 Sukarame Bandar Lampung}

Pada hakekatnya anak usia dini melakukan kegiatan perkembanganya melalui kegiatan bermain sesuai dengan karakteristik anak usia dini yang aktif dalam mengeksplorasi lingkungan sekitar anak, maka bermain sebagian dari suatu proses pembelajaran. Secara langsung atau tidak langsung, bermain menjadi sumber belajar bagi anak usia dini. Dengan bermain anak akan berinteaksi dengan teman, belajar berkomunikasi, belajar memecahkan masalah, dan anak belajar memahami apa yang ada dalam indikator tingkat capaian perkembangan sesuai usianya.

Dengan demikian, evaluasi perkembangan sosial anak kelompok A di Taman Kanak-Kanak Assalam 2 Sukarame Bandar Lampung sudah berjalan dengan baik. Karena dari pengamatan saat kegiatan sehari hari, persiapan rencana kegiatan hariannya, kemudian penilaian harian, catatan-catatan catatan harian anak(anekdot),

\footnotetext{
${ }^{21}$ Peneliti, Hasil observasi, Taman Kanak-Kanak Assalam 2 Sukarame Bandar Lampung,6 April 2015

${ }^{22}$ Peneliti, Hasil observasi, Taman Kanak-Kanak Assalam 2 Sukarame Bandar Lampung, 13 April 2015
} 
buku analisis evaluasi, buku perbaikan dan pengayaan, portofolio, buku kegiatan, hingga buku laporan perkembangan anak sudah digunakan dan berjalan sehingga anak dapat terlihat sejauh mana perkembangan sosialnya dan apakah perlu perbaikan pada anak yang belum berkembang atau mulai berkembang dan tindak lanjut bagi anak-anak yang berkembang sesuai harapan dan berkembang sangat baik.

Oleh Karena itu, seorang guru harus benar-benar memiliki keterampilan dalam menyusun kegiatan kemudian melaksanakan penilaian perkembangan anak salah satunya perkembangan sosial yang sedang diteliti saat ini. Karena hasil evaluasi/penilaian dalam perkembangan anak usia dini dapat memberikan gambaran bagi guru, orangtua, sekolah tentang perkembangan, kondisi, dan kemampuan anak. Penilaian juga sangat berguna sebagai masukan bagi jenjang selanjutnya. Misalnya penilaian pada kelompok A usia 4-5 tahun, berguna saat anak masuk kelompok B 56 tahun.

Adapun tujuan yang diharapkan dari kegiatan evaluasi ini bagi guru dapat mengembangkan dan mensukseskan program kurikulum pendidikan anak usia dini, guru dapat mengidentifikasi apakah anak berkembang sesuai harapan atau belum berkembang. Bagi anak melalui kegiatan yang dilakukan, yang kemudian diamati proses dan hasil pembelajaran anak, lalu dianalisis untuk memprediksi minat dan bakat anak menjadi dasar pengembangan masa depan anak selanjutnya

\section{KESIMPULAN}

Berdasarkan hasil analisis data dari penelitian yang penulis lakukan selama 2 bulan di Taman Kanak-Kanak Assalam 2 Sukarame Bandar Lampung mendapatkan data bahwa analisis evaluasi perkembangan sosial anak kelompok A sudah mengikuti urutan penilaian perkembangan anak usia dini.

Yang bisa dilihat dari awal rencana kegiatan hariannya, penggunaan permaian dalam kegiatan menunjang perkembangan sosial anak, selanjutnya diberikan checklist sesuai kemampuan anak, kemudia semua indikator dimasukkan dalam buku analisis evaluasi kemudian bagi yang belum berkembang sesuai harapan, dimasukkan dalam 
buku perbaikan dan pengayaan. Dan bagi prilaku khusus anak dicatat dalam buku anekdot dan buku bimbingan konseling yang didalamnya terdapa pemecahan masalah, dan tindak lanjut/hasil dan keterangannya.

Semua ini kemudian dikemas dan siap dilaporkan kepada orang tua murid pada akhir semester, yang sering disebut laporan perkembangan anak.Dan disitu guru melaporkan dan menguraikan hasil kegiatan anak selam semester terakhir.

\section{E. DAFTAR PUSTAKA}

Akhmad Muhaimin A.2010. Mengembangkan Kecerdasan Sosial Bagi Anak.Jogjakarta: KATA HATI.

Ali Nugraha dan Yeni Rachmawati.2013. Metode Pengembangan sosial . Emosional.Tanggerang Selatan:Universitas Terbuka.

Asmawati Luluk. 2014. Perencanaan Pembelajaran PAUD. Bandung: PT Remaja Rosda karya.

Christina HS. 2012. Perkembangan Anak. Jakarta: Prenada Media Group.

Departemen Pendidikan Nasional. 2008. KAMUS BESAR BAHASA INDONESIA Jakarta:PT Gramedia.

Dimyanti Johni. 2013. Metodologi Penelitian \& Aplikasinya Pada PAUD. Jakarta: Kencana.

Dokumentasi. 2015. hasil pra survey perkembangan sosial kelompok A. Sukarame Bandar LampungTaman Kanak-Kanak Assalam 2.

Gunarti Winda Dkk. 2010. Metode Perkembangan Prilaku dan Kemampuan Dasar Anak Usia Dini. Jakarta: Universitas Terbuka.

Hurlock Elizabeth B. Child Develovment. Terjemahan Meitasari Tjandrasa. Perkembangan Anak Edisi Keenam. Jakarta: Erlangga.

Jamal Ma'mur. 2009. Manajemen Strategis Pendidikan Anak Usia Dini. Jogjakarta: DIVA Press.

Khairani Makmun. 2013. Psikologi Perkembangan.Yogyakarta:Aswaja Pressindo. Kunandar. 2011. Guru Profesional. Jakarta: Rajawali Pers.

Kurikulum. 2010. Pedoman Pengembangan Program Pembelajaran di Tanan Kanak- Kanak.Yogyakarta: Bina Insan Mulia.

Kurikulum Taman Kanak-Kanak Assalam 2.2015. Sukarame Bandar Lampung.

Lara Firdani Dkk. 2011. Evaluasi Perkembangan Anak Usia Dini. Jakarta: Universitas Terbuka. 